\title{
Distinct immune responses of juvenile and adult oysters (Crassostrea gigas) to viral and bacterial infections
}

\author{
Timothy J. Green ${ }^{1,2}$, Agnes Vergnes ${ }^{1}$, Caroline Montagnani ${ }^{1 *}$ and Julien de Lorgeril ${ }^{1}$
}

\begin{abstract}
Since 2008, massive mortality events of Pacific oysters (Crassostrea gigas) have been reported worldwide and these disease events are often associated with Ostreid herpesvirus type 1 (OsHV-1). Epidemiological field studies have also reported oyster age and other pathogens of the Vibrio genus are contributing factors to this syndrome. We undertook a controlled laboratory experiment to simultaneously investigate survival and immunological response of juvenile and adult C. gigas at different time-points post-infection with OsHV-1, Vibrio tasmaniensis LGP32 and V. aestuarianus. Our data corroborates epidemiological studies that juveniles are more susceptible to OsHV-1, whereas adults are more susceptible to Vibrio. We measured the expression of 102 immune-genes by high-throughput RT-qPCR, which revealed oysters have different transcriptional responses to OsHV-1 and Vibrio. The transcriptional response in the early stages of OsHV-1 infection involved genes related to apoptosis and the interferon-pathway. Transcriptional response to Vibrio infection involved antimicrobial peptides, heat shock proteins and galectins. Interestingly, oysters in the later stages of OsHV-1 infection had a transcriptional response that resembled an antibacterial response, which is suggestive of the oyster's microbiome causing secondary infections (dysbiosis-driven pathology). This study provides molecular evidence that oysters can mount distinct immune response to viral and bacterial pathogens and these responses differ depending on the age of the host.
\end{abstract}

\section{Introduction}

The Pacific oyster, Crassostrea gigas forms the basis of an important global aquaculture industry with one of the largest annual productions of any marine animals. The Pacific oysters is cultivated on all continents, except Antarctica [1]. Oysters are typically reared in the open environment and are therefore vulnerable to the adverse impacts of disease. Historically, C. gigas were chosen in many countries for aquaculture because they were nonnative and naturally resistant to many of the protozoan parasites (Bonamia spp. and Marteilia spp.) that have decimated aquaculture production of indigenous oyster species [2,3]. Sporadic mortality events of adult C. gigas have occurred in many countries over the last four decades [4-6]. These mortality events were often correlated

\footnotetext{
*Correspondence: cmontagn@ifremer.fr

${ }^{1}$ IFREMER, IHPE, UMR 5244, Univ. Perpignan Via Domitia, CNRS, Univ.

Montpellier, 34095 Montpellier, France

Full list of author information is available at the end of the article
}

with elevated seawater temperatures and physiological stresses associated with maturation and spawning [reviewed by 5,6$]$. No specific pathogen was routinely isolated from these sporadic mortality episodes of $C$. gigas [reviewed by 6]. Surveys often isolated viruses belonging to Ostreid herpesvirus type I (OsHV-1) and bacteria belonging to the Vibrio genus [7, 8]. V. splendidus-related strains have been isolated from moribund oysters during mortality events [9] and have been widely described regarding their pathogenicity to bivalves. $V$. aestuarianus has been detected in epidemiologic surveys in oysters and the environment since 2001 [8]. OsHV-1 has been detected in mass mortality outbreaks in hatcheries and in epidemiological surveys since 1993 [10].

Since 2008, mass mortality episodes of C. gigas have dramatically affected juvenile oysters with high intensities and a wide geographic distribution [7, 11]. This syndrome has been associated with the presence of a particular genotype of Ostreid herpesvirus type 1 (OsHV-1), 
termed $\mu$ Var [12]. Mortality associated with this variant was first detected in Europe in 2008 [12], but a closely related genotype has since been associated with mortality of C. gigas in New Zealand and Australia in 2010-2011 $[13,14]$. In Europe, co-detection of the variant and different Vibrio species, including Vibrio tasmaniensis LGP32 and $V$. aestuarianus have been reported during mortality events of C. gigas [7]. These Vibrio species are also considered important pathogens in bivalve aquaculture and may be a contributing factor in the mass mortality episodes $[8,15]$. Host physiology and ontogeny is another key determinant in the mass mortality episodes of $C$. gigas. Younger age classes of $C$. gigas are more susceptible to OsHV-1 infection $[16,17]$, whereas older age classes are reported to be more susceptible to $V$. aestuarianus [8]. Thus, determining how host development influences the immunological response and survival of $C$. gigas is a major goal in understanding the recent mass mortality episodes associated with OsHV-1 and different Vibrio species.

The immunological response of C. gigas against pathogenic viruses and Vibrio bacteria are well documented [18-25]. However, most of these studies focused on a single developmental stage and type of pathogen. To date there has not been a controlled laboratory study to simultaneously investigate the effect of oyster age on the immunological response and survival of $C$. gigas infected with three different pathogens. In this study, we address this question by using high-throughput RT-qPCR to measure the immunological response of juvenile and adult $C$. gigas at different time-points post-infection with OsHV-1, Vibrio tasmaniensis LGP32 and V. aestuarianus.

\section{Materials and methods Crassostrea gigas}

Two different age classes of Crassostrea gigas (juvenile and adult) were chosen for experimentation. Juveniles were produced in March, 2012 at the IFREMER oyster hatchery in La Tremblade, Charente-Maritime, France. Juvenile C. gigas were on-grown in a biosecure nursery facility before being transferred to IFREMER's Aquaculture Research Facility in Palavas-les-Flots (Laboratoire Aquaculture en Languedoc, Roussillon, LALR), France. Juveniles were 7 months old at the time of experimentation. Adult C. gigas were purchased from an Atlantic oyster farm. These adult oysters were naturally collected in 2009 and grown to maturity in a culture area that doesn't experience episodes of summer mortality. Adult C. gigas were 36 months old at the time of experimentation. Although adults and juveniles used in these experiment do not share the same genetic origins, oysters show very high levels of DNA polymorphism [26] and low genetic differentiation between natural populations in
Europe [27] allowing us to compare their transcriptomic patterns. We made sure to use oysters from a multiparental breeding program to avoid emphasizing any genetic impact on a potential variability of susceptibility on viral and bacterial infections. As mentioned earlier, adult and juvenile animals also share similar life traits of life regarding our trait of interest (i.e. pathogen exposure and defense systems) as they were all grown in hatchery structures and never faced mortality events. Prior to experimentation, juvenile and adult $C$. gigas were tested for OsHV-1 and its variants by qPCR according to [28]. No viral DNA was detected using real time PCR analyses on a sample of 10 individual juvenile and adult animals.

\section{Pathogens}

Ostreid herpesvirus type 1 inoculum was prepared according to Schikorski et al. [29]. The nucleotide sequence of the $\mathrm{C}$ region (ORF4) of this OsHV-1 inoculum was PCR amplified according to [30], and had 100\% identity to the OsHV-1 variant $\mu$ Var [31]. This inoculum was estimated to contain $10^{8}$ OsHV-genomes $\mu \mathrm{L}^{-1}$ by qPCR [28] and was confirmed to be free of culturable bacteria by plating $50 \mu \mathrm{L}$ of inoculum on Zobell marine and TCBS agar plates. Two Vibrio inoculums were prepared from $V$. tasmaniensis LGP32 and $V$. aestuarianus $02 / 41$ strains. Both strains were isolated from $C$. gigas undergoing a mortality episode $[9,32]$. Vibrios were grown under agitation at $20{ }^{\circ} \mathrm{C}$ in marine broth 2216 (Difco \#279110) for $18 \mathrm{~h}$. Cultures of $V$. LGP32 and $V$. aestuarianus were centrifuged $\left(1000 \times g, 10 \mathrm{~min}, 20^{\circ} \mathrm{C}\right)$ and resuspended in sterile seawater to an optical density $\left(\mathrm{OD}_{600}\right)$ of 0.50 and 0.05 , respectively.

\section{Experimental challenge}

Juvenile $(\mathrm{N}=750$, Age $=7$ months $)$ and adult $(\mathrm{N}=750$, Age $=36$ months) C. gigas had a notch filed in their shell adjacent to their adductor muscle using an electric bench grinder. Oysters were then returned to their holding tanks $\left(1 \mathrm{~m}^{3}\right)$ that were supplied with continuous renewal of filtered and ultraviolet-sterilised seawater $\left(14{ }^{\circ} \mathrm{C}\right)$ to recover for $24 \mathrm{~h}$. Next, oysters were distributed to 24 aquariums filled with $30 \mathrm{~L}$ of seawater $\left(21 \pm 1{ }^{\circ} \mathrm{C}\right)$ and allowed to acclimatize for $72 \mathrm{~h}$. Each aquarium had either 50 juveniles or 50 adult oysters. At time $0 \mathrm{~h}$, juvenile and adult oysters were injected in the adductor muscle with an inoculum (see "Pathogen" section) containing either sterile seawater (control), OsHV-1, $V$. tasmaniensis or $V$. aestuarianus ( $\mathrm{N}=3$ replicate aquariums per condition) using a 26-gauge needle attached to a multi-dispensing pipette. Juvenile and adult $C$. gigas were injected with either 50 or $100 \mu \mathrm{L}$ of inoculum, respectively, according to the size difference of the animals. Following injection, oysters were assessed daily with dead oysters removed 
from the aquariums and placed in individual plastic bags and snap-frozen with liquid nitrogen and stored at $-80{ }^{\circ} \mathrm{C}$ for further pathogen detection in moribund oysters. Oysters were defined dead when their shell gaped open and remained sprung open after the oyster was removed from its aquarium.

Three juvenile and three adult C. gigas were also sampled from each aquarium at 1, 2, 3, 4 and 7 days post-injection (dpi). The entire oyster was sampled by shucking with a sterile scalpel blade and the three oysters from each aquarium were pooled (three replicate aquariums per condition). Oyster pools were snap-frozen with liquid nitrogen and stored at $-80{ }^{\circ} \mathrm{C}$ until nucleic acid purification for further gene expression analysis and pathogen detection.

\section{Nucleic acid extraction and CDNA synthesis}

Oyster pools and dead oysters were homogenized by bead-beading (Retsch, Mixer Mill MM400) with a stainless steel ball bearing and housing that had been prechilled with liquid nitrogen. Genomic DNA was purified from homogenised oyster tissues using UltraPure Phenol:Chloroform:Isoamyl Alcohol (Invitrogen, \#15593049). Total RNA was purified using TRIzol Reagent (Invitrogen, \#15596-018) and DNA contamination eliminated with rDNase I (Ambion, \#AM2222). Total RNA and DNA were resuspended to a final concentration of 100 and $20 \mathrm{ng} \mu \mathrm{L}^{-1}$, respectively. First-strand synthesis was performed on $500 \mathrm{ng}$ of total RNA using random hexamer primers (Invitrogen, \#48190-011) and M-MLV (Invitrogen, \#28025-013). cDNA was diluted 10-fold with sterile water (DNase- and RNase-free) prior to use.

\section{Pathogen detection and quantification}

Detection and quantification of OsHV-1, V. LGP32 and $V$. aestuarianus genomic DNA was performed using quantitative PCR (qPCR). All amplification reactions were performed in triplicate using a Roche LightCycler 480 Real-Time thermocycler (qPHD-Montpellier GenomiX platform, Montpellier University). PCR reaction volumes were $6 \mu \mathrm{L}$ containing LightCycler 480 SYBR Green I Master mix (Roche), $100 \mathrm{nM}$ of pathogen specific primers and $20 \mathrm{ng}$ of DNA. Pathogen specific primer pairs were obtained from the literature $[28,33,34]$ and their resulting amplification products were cloned into the pCR4Topo vector and replicated in Escherichia coli DH5a (Invitrogen). Plasmids were extracted using the Wizard Plus SV miniprep DNA purification system (Promega) and standard curves of known concentration of plasmid generated according to the Applied Biosystems manual of absolute real-time RT-PCR quantification [35]. Absolute quantification of OsHV-1, V. LGP32 and $V$. aestuarianus genome copies in oyster samples was estimated by comparing the observed $\mathrm{Cp}$ values to known plasmid standards. Primer pairs for $V$. LGP32 and $V$. aestuarianus were confirmed not to cross-react.

\section{High-throughput RT-qPCR and statistical analysis}

High-throughput RT-qPCR was performed by the ACO$\mathrm{BIOM}$ to assess the transcriptomic response of juvenile and adult $C$. gigas to infection with OsHV-1, V. aestuarianus and $V$. tasmaniensis LGP32. We investigated the transcriptional response of 102 immune-related genes, which consisted of 43 putative anti-viral genes and 59 putative anti-bacterial immune genes. It was expected that a proportion of immune genes would be differentially expressed in response to both OsHV-1 and Vibrio infection. The antiviral immune genes were identified in the genome and transcriptome of C. gigas $[36,37,51]$ by performing homology searches (BlastP) using known vertebrate and arthropod antiviral proteins. These proteins have a broad relevance to antiviral immunity, including members of a primitive interferon-response (virusrecognition, signaling), anti-viral effectors, program cell death (autophagy and apoptosis) and RNA interference pathways. Immune genes related to antibacterial immunity were chosen from previous studies investigating the transcriptional response of C. gigas to vibriosis [18, 19]. These genes have been identified to be differentially expressed in oysters capable of surviving an experimental infection with a virulent Vibrio spp ( $V$. tasmaniensis LGP32 and $V$. aestuarianus LPi 02/41) versus an avirulent Vibrio sp. ( $V$. tasmaniensis LMG20012) [18] or were predictive of the capacity of an oyster to survive a virulent Vibrio infection [19]. These 59 immune genes belong to six functional categories, including immunity (recognition, signaling and effector molecules), cellular adhesion and differentiation, cytoskeleton reorganization, apoptosis and oxidative stress. Lastly, three housekeeping genes were also included as internal controls for normalising the data (Cg-EF1, GenBank \#AB122066; Cg-RPL40, \#FP004478; Cg-RPS6, \#HS119070). Additional file 1 provides the GenBank accession number for each target gene, designated immunological function and the nucleotide sequences for each primer pair.

The mRNA expression levels of the chosen target and internal reference genes were determined in juvenile and adult $C$. gigas at 1,2, 3 and 4 days post-inoculation. The total qPCR reaction volume was $0.5 \mu \mathrm{L}$ and consisted of $0.25 \mu \mathrm{L}$ of cDNA (ng) and $0.25 \mu \mathrm{L}$ of LightCycler ${ }^{\circledR} 1536$ DNA Green Master Kit (Roche) containing $0.55 \mu \mathrm{M}$ of PCR primer (Eurogenetec). Pipetting into the 1536 well-plate (Roche) was performed with Labcyte Acoustic Automated Liquid Handling Platform (ECHO). The LightCycler $^{\circledR} 1536$ Instrument (Roche) was used with the following program: enzyme activation of $95{ }^{\circ} \mathrm{C}$ for 
1 min followed by 45 cycles of denaturation $\left(95^{\circ} \mathrm{C}, 2 \mathrm{~s}\right)$ and hybridization-elongation $\left(60^{\circ} \mathrm{C}, 30 \mathrm{~s}\right)$. A subsequent melting temperature curve of the amplicon was performed to verify the specificity of the RT-qPCR reaction. The amplification efficiency of each primer pair was previously validated using a serial dilution of cDNA and only primer pairs with efficiency of $2 \pm 0.1$ were used for gene expression analysis. The RT-qPCR data was normalised using the $2^{(\Delta \Delta C T)}$ method [38] using elongation factor 1 (GenBank AB122066) as the internal reference gene.

Statistical analysis of qPCR data was performed separately for juvenile and adult oysters. Two-way analysis of variance (ANOVA) was conducted to individually assess expression levels of the 102 target genes using the univariate general linear model (GLM) with post hoc Tukey's HSD test in IBM SPSS Statistics v 20.0. The two factors analysed were "PATHOGEN" with four levels (OsHV-1, $V$. tasmaniensis LGP32, $V$. aestuarianus \& seawater) and "TIME" (1, 2, 3 and 4 days). When interactions between these factors were non-significant, these terms were removed from the model to test for single-order effects alone. Hierarchical clustering was performed on target genes identified to be differential expressed using Multiple Array Viewer software (version 4.6.2). Clustering analysis was performed with Pearson correlation based distance.

\section{Results}

\section{Oyster mortality and pathogen DNA detection}

Minimal mortality of controls Crassostrea gigas occurred during experimentation (juvenile and adult $>97 \%$ survival, sterile seawater injection or non-treated controls). Juveniles were more susceptible to OsHV-1 infection than adult $C$. gigas (Figure 1). Overall, $60 \%$ of juveniles succumbed to OsHV-1 with peak mortality occurring 3 dpi leading to $40 \%$ survival 7 dpi (Figure 1A) whereas, $30 \%$ of adult C. gigas succumbed to OsHV-1 and mortality peaked on day 5 leading to $70 \%$ survival $7 \mathrm{dpi}$ (Figure 1B). The concentration of OsHV-1 DNA in juvenile and adult tissues was below detectable limits on day zero, but rapidly increased following injection with the OsHV-1 inoculum. The average concentration of OsHV-1 DNA in juveniles peaked at $2 \mathrm{dpi}$ with $7.7 \cdot 10^{6}$ genome copies $\mathrm{ng}^{-1}$ of genomic DNA (Figure 2A). The concentration of OsHV-1 DNA in adult oysters was consistently lower than in juveniles and peaked at 3-4 dpi with $4 \cdot 10^{3}$ genome copies $\mathrm{ng}^{-1}$ of genomic DNA (Figure 2A). The average viral DNA in moribund juvenile and adult tissues was considerably higher at $2.4 \cdot 10^{7}$ and $5.5 \cdot 10^{5}$ genome copies $\mathrm{ng}^{-1}$ of genomic DNA, respectively.

In contrast to OsHV-1 infection, adult C. gigas were more susceptible to Vibrio infection than juveniles


Figure 1 Kaplan-Meier survival curves. Survival curves for juvenile (A) and adult (B) oysters injected with seawater (SW, dark blue line) or non-treated (NT, light blue line), OsHV-1 inoculum (red), Vibrio tasmaniensis LGP32 (yellow), V. aestuarianus (purple).

(Figure 1). Overall, 63 and $70 \%$ of adult C. gigas died of $V$. aestuarianus and $V$. tasmaniensis LGP32 infection, respectively (37 and $30 \%$ survival, Figure $1 \mathrm{~A}$ ). V. tasmaniensis LGP32 infection induced mortality of adult $C$. gigas was rapid with peak mortality occurring at $2 \mathrm{dpi}$, whereas peak mortality of adult $C$. gigas infected with $V$. aestuarianus occurred later at $4 \mathrm{dpi}$ (Figure 1B). Juveniles suffered 37 and $43 \%$ mortality to V. aestuarianus and $V$. tasmaniensis LGP32, respectively (63 and 57\% survivalFigure 1B). The average concentration of $V$. tasmaniensis LGP32 DNA peaked at $2 \mathrm{dpi}$, at $2 \cdot 10^{6}$ and $4 \cdot 10^{5}$ genome copies.ng ${ }^{-1}$ of DNA isolated from juvenile and adult tissues (Figure 2B). Whereas, the average concentration of $V$. aestuarianus DNA peaked later at 4 and $3 \mathrm{dpi}$ for juvenile and adult tissues, respectively (Figure $2 \mathrm{C}$ ). The average concentration of $V$. tasmaniensis LGP32 DNA in moribund oysters reached $10^{8}$ and $10^{7}$ genome copies of $V$. tasmaniensis LGP32 $\mathrm{ng}^{-1}$ of genomic DNA isolated from individual juvenile and adult moribund oysters, respectively. The average concentration of $V$. aestuarianus DNA was higher in moribund oysters with $10^{7}$ and $2 \cdot 10^{6}$ genome copies of $V$. aestuarianus.ng ${ }^{-1}$ of genomic DNA isolated from individual juvenile and adult moribund oysters, respectively. 




Distinct immune response in juvenile and adult $C$. gigas

The temporal expression profile of 102 target genes and 3 internal reference genes was analysed by high-throughput RT-qPCR to determine the transcriptional response of juvenile and adult $C$. gigas to pathogen infection at $1,2,3$ and 4 days post-infection. The high-throughput RT-qPCR analyses generated 10080 individual Cq values. Statistical analysis revealed that a total of 30 and 27 target genes were differentially expressed in response to pathogen infection in juvenile and adult $C$. gigas, respectively (two-way ANOVA, $p<0.05$ ) (see Additional file 2 for details). The majority of genes regulated in response to pathogen infection in juvenile and adult $C$. gigas belonged to the following functional categories: cellular adhesion (i.e. neural-cadherin), heat-shock proteins (i.e. sHSP, HSP $68 \mathrm{kDa}$ ), apoptosis (i.e. TNF ligand and IAP), non-self recognition (i.e. galectin) and pathogen recognition (i.e. toll-like receptors, rig-like receptors, c-type lectins), signaling molecules (i.e. MyD88, ІкB, IRF-8 and SOC-1), antiviral effectors (i.e. viperin, ADAR-L, OAS, PKR and IFI44) and antimicrobial peptides (i.e. big defensin).

Comparison of transcriptome data from juvenile and adult C. gigas revealed specific response to juvenile or adult stages. Sixteen genes were common to the early response to pathogen in juveniles and adults with 14 and 11 specific to the adult or juvenile response, respectively (Figure 3A). Several immune genes are also differentially expressed in adults and juveniles in response to the same pathogen. Concerning specific response of juveniles compared to adults, 9 genes were found to be specifically regulated in response to OsHV-1, 3 to $V$. aestuarianus and 2 to $V$. tasmaniensis LGP32 (Figure 3B). In the case of OsHV-1 infections, inhibitor of apoptosis (IAP) are up-regulated in juvenile $(p<0.05)$, but OsHV-1 $\mu$ Var infection does not influence the expression of IAP in adults $(p>0.05)$. Signaling molecules (IRAK-4, IкB) in the NF- $\mathrm{kB}$ pathway are also exclusively up-regulated in juveniles inoculated with OsHV-1 $\mu \operatorname{Var}(p<0.05)$, but not in adults. For Vibrio infections, several genes also appeared differentially expressed specifically at one developmental stage. Some genes appear only regulated in juveniles as big defensin, TGF, ilntegrin-binding protein, and cdc42 homolog. Concerning specific response of adults compared to juveniles, 10 genes were found to be specifically regulated in response to OsHV-1, and 1 to

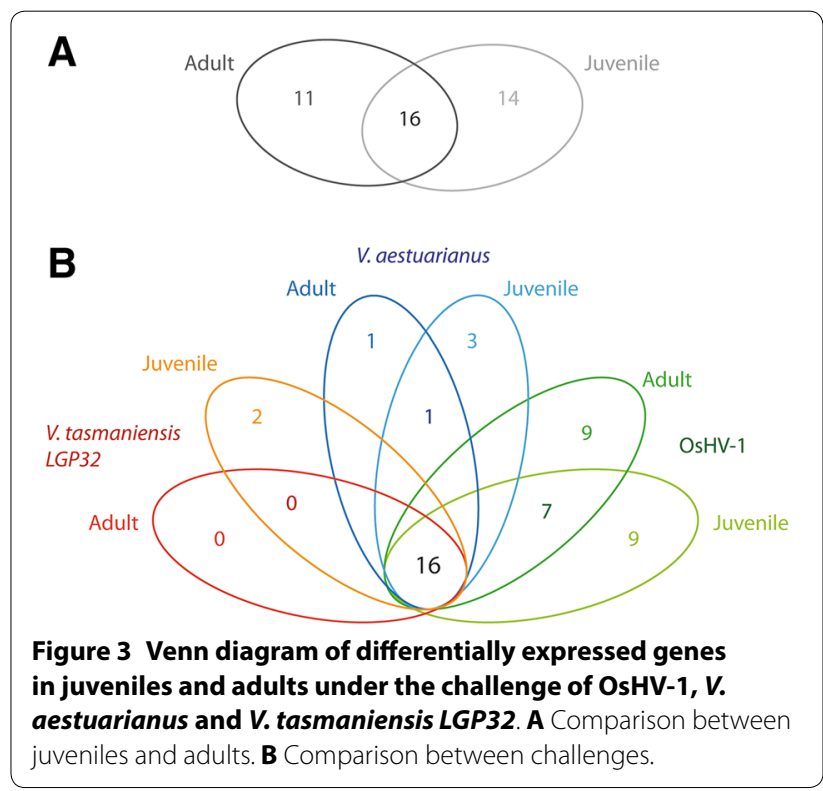


V. aestuarianus (Figure 3B). Interestingly, only adult $C$. gigas differentially express the autophagy related protein (Atg8/LC3) in response to pathogen infection $(p<0.05)$. Other genes differentially expressed in adult $C$. gigas include gamma interferon inducible lysosomal thiol reductase (GILT-1, GILT-2), interleukin receptor, a c-type lectin, early growth response protein (EGR), poly(U) endoribonuclease, MEGF10, metallothionein and extracellular superoxide dismutase (EcSOD) $(p<0.05)$.

\section{Distinct early response to viral and bacterial infection}

Hierarchical clustering of these differentially expressed genes in response to pathogen infection across all time points revealed juvenile and adult $C$. gigas have a distinct molecular signature to viral and bacterial infection (Figures 4 and 5). Adult and juvenile transcriptomic data were treated separately according to their differences in life stages and backgrounds. Figure 4 revealed the transcriptional response of juveniles in the early stages of OsHV-1 infection (juvenile cluster J1) involves the regulation of a group of immune genes involved in apoptosis and a primitive interferon response (gene cluster G2). In contrast, juveniles in the early (cluster J3), mid (cluster J2) and late (cluster J4) stages of Vibrio infection have a distinct transcription response involving regulation of a set of genes involved in a broad range of functions, including cellular proliferation (i.e. TGF ligand), adhesion (i.e. neural-cadherin and integrin-binding protein), migration (i.e. CDC42 homolog), and immune response (i.e. galectin, big defensin, HSPs and cystatin B) (gene cluster G1). Interestingly, genes from the G2 cluster globally appeared not regulated in response to bacterial infection. There was no clear distinction in the transcriptional response of spat to $V$. aestuarianus and $V$. tasmaniensis LGP32 (Figure 4).

As for juveniles, adult $C$. gigas displayed a distinct transcriptional response to OsHV-1 $\mu$ Var and Vibrio infection (Figure 5). Hierarchical clustering reveals adult oysters in the early stages of OsHV-1 infection (adult cluster A2) also have a distinct anti-viral response involving up-regulation of interferon-related genes (gene cluster G2). Whereas, adult C. gigas infected with Vibrio cluster into an early (clusters A1 and A3) and late (cluster A4) groups (Figure 5) involving differential gene expression of a set of genes involved in molecular functions, including cellular differentiation (i.e. $\operatorname{poly}(\mathrm{U})$ specific endoribonuclease-D and TNF), cellular adhesion (i.e. neural-cadherin), immune response (i.e. HSP $68 \mathrm{kDa}$, galectin, interleukin receptor, MyD88), and oxidative stress (i.e. EcSOD) (gene cluster G1). Similar to juveniles, no clear distinction was observed in the transcriptional response of adult $C$. gigas to $V$. aestuarianus and V. tasmaniensis LGP32 (Figure 5).
The transcriptional response of juvenile and adult C. gigas in the later stages of OsHV-1 infection (4 dpi) is similar to C. gigas samples inoculated with Vibrio (Figures 4 and 5).

\section{Discussion}

This study provides the first direct comparison of the transcriptional responses of juvenile and adult Crassostrea gigas to viral (OsHV-1) and bacterial (Vibrio tasmaniensis LGP32 and $V$. aestuarianus) pathogens. Data from this experiment provides some important insights into the molecular basis of the mass mortality events of cultivated C. gigas that are currently occurring in many countries $[12-14,17]$. The observed mortality in our experiment corroborates recent epidemiological field studies that revealed juveniles are more susceptible to viral infection with OsHV-1 $[16,17]$ and reports that adult $C$. gigas are more susceptible to bacterial infection with Vibrio [39]. Although juvenile oysters have been demonstrated to also be susceptible to $V$. aestuarianus in controlled experiments, this pathogen has been predominantly associated with adult oyster mortality events and adult oysters seem to be more susceptible to this bacterium than spat (i.e. young juvenile oysters) $[8,39]$. We measured the concentration of OsHV-1 DNA in juvenile and adult tissues by qPCR (Figure 2A), which revealed the rate of OsHV-1 replication is greater in juveniles with the maximum concentration of OsHV-1 DNA occurring earlier in juveniles (Figure 2A). The earlier peak in OsHV-1 DNA coincides with mortality occurring earlier for juveniles compared to adults (Figure 1). Our results are in accordance with previous studies where the level of cumulative mortality using injection as the method of OsHV-1 inoculation varies according to the age and genetics of the host, but typically ranges between 15 and $90 \%[21,22,25,29,40,41]$. However, if OsHV-1 is known to be harmful to larvae, spats and juveniles, it has been generally accepted that adults are much more resistant to the virus and found to be asymptomatic carriers. Consequently, little attention has been paid to adult susceptibility to OsHV-1. A few studies have recorded vial DNA loads in adult oysters, which were associated with lower mortalities and no clear link was established with abnormal mortalities [16, 17, 42-47]. It has been suggested that these observations could reflect the fact that adult oysters may have survived previous mortality events and consequently became resistant to the disease $[17,42,43$, 48]. However, more recent studies, concurring with our results, have confirmed that juveniles mortalities are more important, but also that adult oysters can be susceptible to viral infection in experimental conditions with mortalities reaching a mean of $27.5 \%$ at 6 days post-infection [21]. The authors suggested that in the case of adults, 


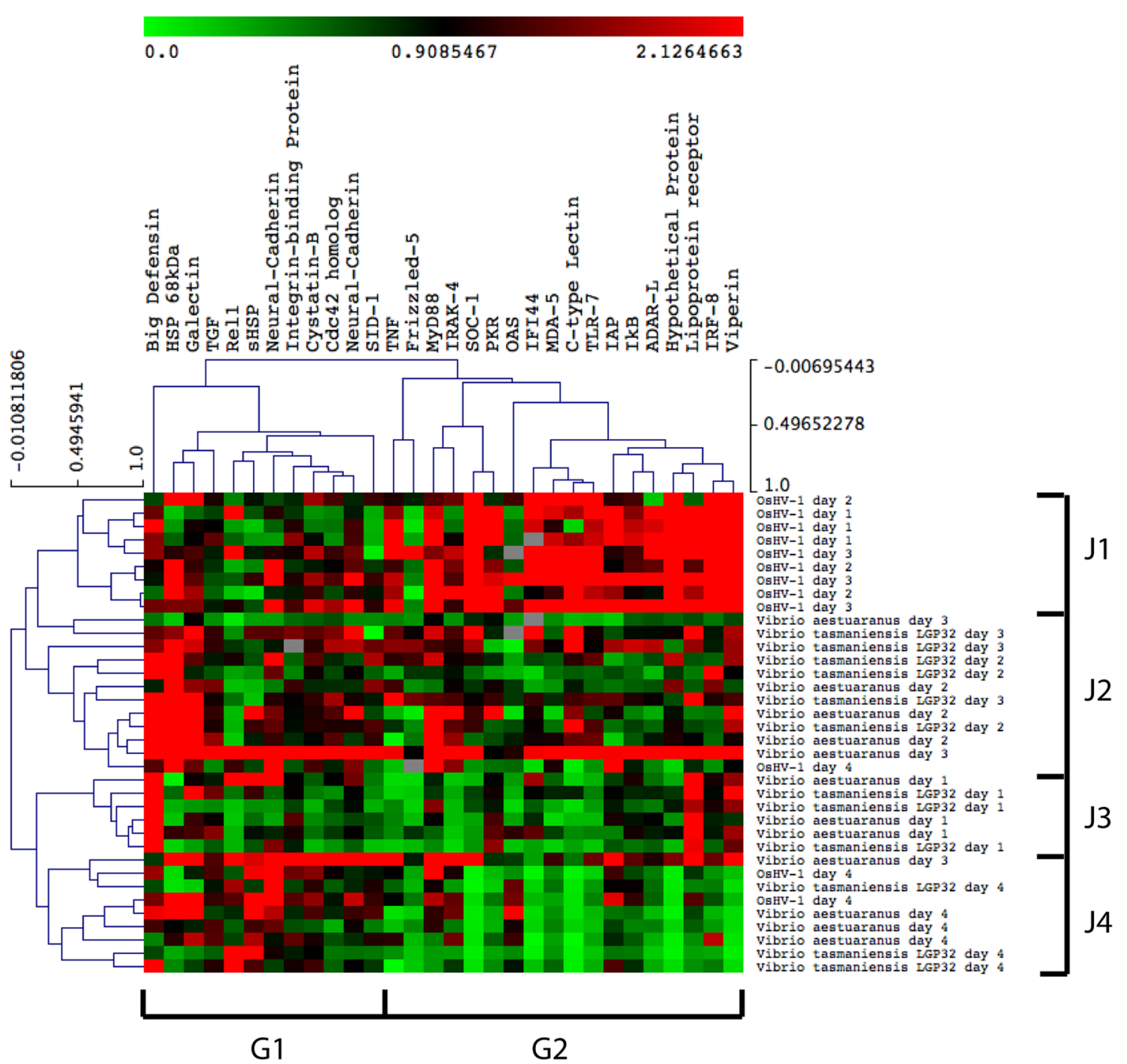

Figure 4 Heat map depicting the expression of immune genes of juvenile Crassostrea gigas infected with OsHV-1, Vibrio aestuarianus and V. tasmaniensis LGP32. The expression of each target gene was normalised to the transcript level of control groups (juvenile injected with sterile seawater) at each sampling time point (1,2,3 and 4 days post-injection). Hierarchical clustering confirms that juvenile have a distinct antiviral and anti-bacterial response. Juveniles in the early stages of OsHV-1 infection (J1) cluster separately to juveniles in the early (J3), mid (J2) and late (J4) stages of Vibrio infection. No distinction in the transcriptional response was observed between juvenile infected with V. aestuarianus or V.LGP32. Juveniles in the early stages of OsHV-1 infection have a transcriptional response involving the up-regulation of genes in cluster G2, whereas Vibrio infection results in the up-regulation of genes in cluster $\mathrm{G} 1$.

the apoptosis pathway might be involved to circumvent virus infection, ultimately reducing the viral DNA load in oyster tissues along the time of experiment [21].

Transcriptome data from high-throughput RT-qPCR analysis of the C. gigas immune response also provides useful insights into the molecular basis for the massive mortality events. Hierarchical clustering analysis of differentially expressed genes revealed the transcriptomic response of juvenile and adult $C$. gigas inoculated with $V$. tasmaniensis LGP32 and $V$. aestuarianus was distinctly different to C. gigas in the early stages of OsHV-1 infection (Figures 3 and 4). These observations suggest the immune response of $C$. gigas can distinguish and tailor specific responses to bacterial and viral pathogens.

In the early stages of OsHV-1 infection, juvenile and adult $C$. gigas displayed a specific antiviral response involving genes related to apoptosis (TNF ligand, IAP), virus recognition (i.e. TLR, MDA-5, C-type lectins, frizzled, lipoprotein receptor), immune-signaling (i.e. MyD88, IKB, IRAK, IRF-8, SOC-1) and antiviral effectors 




Figure 5 Heat map depicting the expression of immune genes of adult Crassostrea gigas infected with OsHV-1, Vibrio aestuarianus and $\boldsymbol{V}$. tasmaniensis LGP32. The expression of each target gene was normalised to the transcript level of control groups (adults injected with sterile seawater) at each sampling time point (1,2,3 and 4 days post-injection). Adult oysters in the early stages of OsHV-1 infection (A2) cluster separately to adult oysters in the early (A3) and late (A4) stages of Vibrio infection. Hierarchical clustering did not reveal a distinction in the transcriptional response of adult C. gigas infected with V. aestuarianus or V. tasmaniensis LGP32.

(i.e. viperin, IFI44, ADAR-L, PKR). Some studies have suggested that the higher mortality of juveniles is because their immune system is immature [13], but our results, concurring with recent studies [21-23, 25], clearly showed that juveniles, as for adults, are able to mount an antiviral response, which is manifested by the regulation of these numerous immune genes. Moreover, we showed here those juvenile oysters are more able to circumvent bacterial infection as opposed to adults. Interestingly, adults and juveniles seem to demonstrate a common response to OsHV-1 through an IFN-like pathway. Animals in the vertebrate phylum express the same recognition, signaling and effector genes in response to viruses, dsRNA and interferon cytokines $[49,50]$, which has led several authors to conclude that C. gigas have a interferon-like response $[25,51,52]$. The antiviral effectors induced by interferon control viruses by directly targeting pathways and functions required during the viruses life-cycle, including cellular entry, translation and replication of the viruses genome, and exit in order to infect 
new cells [50]. All of the effector molecules (viperin, ADAR-L, IFI44, OAS and PKR) induced by OsHV-1 are known to have direct antiviral activity by inhibiting virus replication via targeting synthesis (transcription and translation) of both host and viral proteins in vertebrates [reviewed by 50]. The number and magnitude of antiviral effectors induced by juvenile $C$. gigas was greater than adults, which may result from the higher concentration of OsHV-1 DNA in juvenile tissues (Figure 2). Previous studies indeed show a positive correlation between the expression level of specific immune genes (MyD88, IFI44, IкB2) and viral DNA loads [22]. From the host perspective, having a weaker antiviral response may be preferable to over-expressing a group of extremely potent antiviral effectors, as the latter could result in a toxic cellular environment [53]. In addition, we noticed that juveniles, in contrast to adults, are specifically regulating a number of NF-kB pathway components (IRAK, IкB, MyD88) and a distinct TLR. These genes were also up-regulated in previous studies, confirming our results [21-23, 25]. Although there is a functional link between the noncanonical NF-kB and the IFN response [54, 55], the NF- $\mathrm{kB}$ pathway is commonly regarded as a major regulator of the innate immune defense to bacterial or viral infection [56, 57]. This pathway is activated in response to a variety of stimuli, including viral and bacterial infections, exposure to pro-inflammatory cytokines, mitogens and growth factors, and stress-inducing agents [57-59]. Moreover, several studies indicate that viruses have acquired the capability to reprogram NF- $\mathrm{kB}$ antiviral activity and to exploit the factor for efficient replication [60]. These finding might reveal that juveniles are unable to properly tailor their antiviral response and display a more pleiotropic response resulting in different susceptibilities or response efficiencies.

Hierarchical clustering analysis failed to differentiate a clear transcriptional response between $V$. tasmaniensis LGP32 and V. aestuarianus (Figures 4 and 5), which suggests either that the immune response of $C$. gigas does not distinguish between these bacterial pathogens. Although, Zhang et al. showed that the transcriptional response to distinct bacteria and vibrios can vary, to our knowledge, there is no record of comparison between these vibrios strains [23]. Further global transcriptomic analyses will be needed to access the subtle difference that may exist between these two responses. However, temporal changes in the transcriptional response to Vibrio infection were evident with expression profiles clustering into early and late responses (Figures 3 and 4). Interestingly, C. gigas in the latter stages of OsHV-1 infection had a transcriptomic response that is undistinguishable to $C$. gigas infected with Vibrio. Bacteria belonging to the Vibrio genus are known to be a common component of the oyster's microbiome [61, 62] and the transcriptomic data might suggest Vibrio were causing a co-infection in the later stages of the OsHV-1 challenge. Indeed, the detection frequency and quantity of Vibrio DNA in C. gigas tissue is known to increase markedly during field mortality events where OsHV-1 is diagnosed as the primary pathogen [42, 63]. Our transcriptomic data provides further support of a multi-pathogen etiology in the massive mortality events currently occurring in Europe [15, 42].

In summary, we showed that oysters are able to mount distinct immune responses to bacterial or viral pathogens. These responses differ depending on the age of the animals. These data provide pathogen specific sets of genes and a unique opportunity to further investigate the role played by different pathogens in these multifactorial mortality events. Future research should focus on investigating the role of the oyster's microbiome in the development of the mass mortality events of C. gigas overwhelming the majority of countries that farm the Pacific oyster. Such studies would help to decipher the role played by other opportunistic pathogens during the course of the mass mortality events that are associated with Ostreid herpesvirus type 1 infection.

\section{Additional files}

Additional file 1. List of primer from antiviral and antibacterial gene selection. Table listing primers used in the high throughput RTQPCR analysis with their respective nucleic sequence, Genbank reference and BLAST hits.

Additional file 2. List of regulated genes in juveniles and adults in response response to OsHV-1, V. aestuarianus and V. tasmaniensis LGP32. Statistical analysis of qPCR data was performed separately for juvenile and adult oysters. Two-way analysis of variance (ANOVA) was conducted to individually assess expression levels of the 102 target genes using the univariate general linear model (GLM) with post hoc Tukey's HSD test in IBM SPSS Statistics v 20.0

Competing interests

The authors declare that they have no competing interests.

\section{Authors' contributions}

$C M, J d L$ and $T G$ designed the primers, designed the experiment and drafted the manuscript. CM, JdL and TG carried out the experimental infection. TG, JdL and AV carried out the RNA extractions and CDNA synthesis. TG performed the pathogen load analyses. TG and JdL performed the statistical analyses. All authors read and approved the final manuscript.

\section{Acknowledgements}

The authors wish to thank Marc Leroy for laboratory assistance at IHPE as well as F. Ruelle for technical assistance at the Palavas-les-Flots Ifremer station. The authors are grateful to Delphine Destoumieux-Garzón for fruitful discussions and mentorship. The authors acknowledge the IFREMER hatchery team (LGPMM) in La Tremblade and the nursery team (LSPC) in Bouin for the production of juvenile oysters. The authors are also thankful to the Acobiom company team (D. Piquemal, F. Noguier, R. Bruno) for technical support, experimental design assistance and statistical support. The authors are finally thankful to Philippe Clair from the qPHD platform/Montpellier genomix for 
useful advices. We thank Jean-Michel Escoubas for his useful comments on the original manuscript. This work was financially supported by IFREMER.

\section{Author details}

1 IFREMER, IHPE, UMR 5244, Univ. Perpignan Via Domitia, CNRS, Univ. Montpellier, 34095 Montpellier, France. ${ }^{2}$ Present Address: Department of Biological Sciences, Macquarie University, Sydney, NSW 2109, Australia.

Received: 27 January 2016 Accepted: 2 May 2016 Published online: 21 July 2016

\section{References}

1. Hedgecock D, Gaffney PM, Goulletquer P, Guo X, Reece KS, Warr GW (2005) The case for sequencing the Pacific oyster genome. J Shellfish Res 24:429-441

2. Carnegie RB, Cochennec-Laureau N (2004) Microcell parasites of oysters: recent insights and future trends. Aquat Living Resour 17:519-528

3. Berthe FCJ, Roux FL, Adlard RD, Figueras A (2004) Marteiliosis in molluscs: a review. Aquat Living Resour 17:433-448

4. Chaney ML, Gracey AY (2011) Mass mortality in Pacific oysters is associated with specific gene expression signature. Mol Ecol 20:2942-2954

5. Li Y, Qin JG, Abbott CA, Li X, Benkendorff K (2007) Synergistic impacts of heat shock and spawning on the physiology and immune health of Crassostrea gigas: an explanation for summer mortality in Pacific oysters. Am J Physiol Regul Integr Comp Physiol 293:R2353-R2362

6. Samain JF, Degremont L, Soletchnik P, Haure J, Bedier E, Ropert M, Moal J, Huvet A, Bacca H, Van Wormhoudt A, Delaporte M, Costil K, Pouvreau S, Lambert C, Boulo V, Soudant P, Nicolas J-L, Le Roux F, Renault T, Gagnaire B, Geret F, Boutet I, Burgeot T, Boudry P (2007) Genetically based resistance to summer mortality in the Pacific oyster (Crassostrea gigas) and its relationship with physiological, immunological characteristics and infection processes. Aquaculture 268:227-243

7. Barbosa Solomieu V, Renault T, Travers MA (2015) Mass mortality in bivalves and the intricate case of the Pacific oyster, Crassostrea gigas. J Invertebr Pathol 131:2-10

8. Travers MA, Boettcher Miller K, Roque A, Friedman CS (2015) Bacterial diseases in marine bivalves. J Invertebr Pathol 131:11-31

9. Garnier M, Labreuche Y, Garcia C, Robert M, Nicolas J-L (2007) Evidence for the involvement of pathogenic bacteria in summer mortalities of the Pacific oyster Crassostrea gigas. Microb Ecol 53:187-196

10. Garcia C, Thebault A, Degremont L, Arzul I, Miossec L, Robert M, Chollet B, Francois C, Joly JP, Ferrand S, Kerdudou N, Renault T (2011) Ostreid herpesvirus 1 detection and relationship with Crassostrea gigas spat mortality in France between 1998 and 2006. Vet Res 42:73

11. Green TJ, Raftos D, Speck P, Montagnani C (2015) Antiviral immunity in marine molluscs. J Gen Virol 96:2471-2482

12. Segarra A, Pepin JF, Arzul I, Morga B, Faury N, Renault T (2010) Detection and description of a particular Ostreid herpesvirus 1 genotype associated with massive mortality outbreaks of Pacific oysters, Crassostrea gigas, in France in 2008. Virus Res 153:92-99

13. Jenkins C, Hick P, Gabor M, Spiers Z, Fell SA, Gu X, Read A, Go J, Dove M, O'Connor W, Kirkland PD, Frances J (2013) Identification and characterisation of an Ostreid herpesvirus-1 microvariant (OsHV-1 $\mu \mathrm{Var}$ ) in Crassostrea gigas (Pacific oysters) in Australia. Dis Aquat Organ 105:109-126

14. Keeling SE, Brosnahan CL, Williams R, Gias E, Hannah M, Bueno R, McDonald WL, Johnston C (2014) New Zealand juvenile oyster mortality associated with Ostreid herpesvirus 1-an opportunistic longitudinal study. Dis Aquat Organ 109:231-239

15. Petton B, Bruto M, James A, Labreuche Y, Alunno Bruscia M, Le Roux F (2015) Crassostrea gigas mortality in France: the usual suspect, a herpes virus, may not be the killer in this polymicrobial opportunistic disease. Front Microbiol 6:686

16. Paul-Pont I, Evans O, Dhand NK, Rubio A, Coad P, Whittington R (2014) Descriptive epidemiology of mass mortality due to Ostreid herpesvirus-1 (OsHV-1) in commercially farmed Pacific oysters (Crassostrea gigas) in the Hawkesbury River estuary, Australia. Aquaculture 422:146-159
17. Peeler EJ, Allan Reese R, Cheslett D, Geoghegan F, Power A, Thrush MA (2012) Investigation of mortality in Pacific oysters associated with Ostreid herpesvirus-1 $\mu$ Var in the Republic of Ireland in 2009. Prev Vet Med 105:136-143

18. de Lorgeril J, Zenagui R, Rosa R, Piquemal D, Bachere E (2011) Whole transcriptome profiling of successful immune response to Vibrio infections in the oyster Crassostrea gigas by digital gene expression analysis. PLoS One 6:e23142

19. Rosa RD, de Lorgeril J, Tailliez P, Bruno R, Piquemal D, Bachere E (2012) A hemocyte gene expression signature correlated with predictive capacity of oysters to survive Vibrio infections. BMC Genom 13:252

20. Renault T, Faury N, Barbosa-Solomieu V, Moreau K (2011) Suppression substractive hybridisation (SSH) and real time PCR reveal differential gene expression in the Pacific cupped oyster, Crassostrea gigas, challenged with Ostreid herpesvirus 1. Dev Comp Immunol 35:725-735

21. Segarra A, Baillon L, Tourbiez D, Benabdelmouna A, Faury N, Bourgougnon $\mathrm{N}$, Renault T (2014) Ostreid herpesvirus type 1 replication and host response in adult Pacific oysters, Crassostrea gigas. Vet Res 45:103

22. Segarra A, Mauduit F, Faury N, Trancart S, Dégremont L, Tourbiez D, Haffner P, Barbosa-Solomieu V, Pepin J-F, Travers M-A, Renault T (2014) Dual transcriptomics of virus-host interactions: comparing two Pacific oyster families presenting contrasted susceptibility to Ostreid herpesvirus 1. BMC Genom 15:580

23. Zhang L, Li L, Guo X, Litman GW, Dishaw LJ, Zhang G (2015) Massive expansion and functional divergence of innate immune genes in a protostome. Sci Rep 5:8693

24. Rosani U, Varotto L, Domeneghetti S, Arcangeli G, Pallavicini A, Venier P (2015) Dual analysis of host and pathogen transcriptomes in Ostreid herpesvirus 1-positive Crassostrea gigas. Environ Microbiol 17:4200-4212

25. He Y, Jouaux A, Ford SE, Lelong C, Sourdaine P, Mathieu M, Guo X (2015) Transcriptome analysis reveals strong and complex antiviral response in a mollusc. Fish Shellfish Immunol 46:131-144

26. Sauvage C, Bierne N, Lapegue S, Boudry P (2007) Single nucleotide polymorphisms and their relationship to codon usage bias in the Pacific oyster Crassostrea gigas. Gene 406:13-22

27. Meistertzheim AL, Arnaud-Haond S, Boudry P, Thebault MT (2013) Genetic structure of wild European populations of the invasive Pacific oyster Crassostrea gigas due to aquaculture practices. Mar Biol 160:453-463

28. Pepin JF, Riou A, Renault T (2008) Rapid and sensitive detection of Ostreid herpesvirus 1 in oyster samples by real-time PCR. J Virol Methods 149:269-276

29. Schikorski D, Renault T, Saulnier D, Faury N, Moreau P, Pepin JF (2011) Experimental infection of Pacific oyster Crassostrea gigas spat by Ostreid herpesvirus 1: demonstration of oyster spat susceptibility. Vet Res 42:27

30. Renault T, Arzul I (2001) Herpes-like virus infections in hatchery-reared bivalve larvae in Europe: specific viral DNA detection by PCR. J Fish Dis 24:161-167

31. Segarra A, Pepin JF, Arzul I, Morga B, Faury N, Renault T (2010) Detection and description of a particular Ostreid herpesvirus 1 genotype associated with massive mortality outbreaks of Pacific oysters, Crassostrea gigas, in France in 2008. Virus Res 153:92-99

32. Gay M, Renault T, Pons A-M, Le Roux F (2004) Two Vibrio splendidus related strains collaborate to kill Crassostrea gigas: taxonomy and host alterations. Dis Aquat Organ 62:65-74

33. Duperthuy M, Binesse J, Le Roux F, Romestand B, Caro A, Got P, Givaudan A, Mazel D, Bachere E, Destoumieux-Garzon D (2010) The major outer membrane protein OmpU of Vibrio splendidus contributes to host antimicrobial peptide resistance and is required for virulence in the oyster Crassostrea gigas. Environ Microbiol 12:951-963

34. Saulnier D, De Decker S, Haffner P (2009) Real-time PCR assay for rapid detection and quantification of Vibrio aestuarianus in oyster and seawater: a useful tool for epidemiologic studies. J Microbiol Methods 77:191-197

35. Applied_Biosystems (2003) Creating standard curves with genomic DNA or plasmid DNA templates for use in quantitative PCR. http://www. appliedbiosystems.com/support/tutorials/pdf/quant_pcr.pdf. Accessed 20 June 2007

36. Zhang G, Fang X, Guo X, Li L, Luo R, Xu F, Yang P, Zhang L, Wang X, Qi H, Xiong Z, Que H, Xie Y, Holland PW, Paps J, Zhu Y, Wu F, Chen Y, Wang J, Peng C, Meng J, Yang L, Liu J, Wen B, Zhang N, Huang Z, Zhu Q, Feng Y, Mount A, Hedgecock D, Xu Z et al. (2012) The oyster genome reveals stress adaptation and complexity of shell formation. Nature 490:49-54 
37. Fleury E, Huvet A, Lelong C, de Lorgeril J, Boulo V, Gueguen Y, Bachère E, Tanguy A, Moraga D, Fabioux C, Lindeque P, Shaw J, Reinhardt R, Prunet P, Davey G, Lapègue S, Sauvage C, Corporeau C, Moal J, Gavory F, Wincker P, Moreews F, Klopp C, Mathieu M, Boudry P, Favrel P (2009) Generation and analysis of a 29,745 unique expressed sequence tags from the Pacific oyster (Crassostrea gigas) assembled into a publicly accessible database: the GigasDatabase. BMC Genomics 10:341

38. Livak KJ, Schmittgen TD (2001) Analysis of relative gene expression data using real-time quantitative PCR and the 2-DDCT method. Methods 25:402-408

39. Azema P, Travers MA, De Lorgeril J, Tourbiez D, Degremont L (2015) Can selection for resistance to OsHV-1 infection modify susceptibility to Vibrio aestuarianus infection in Crassostrea gigas? First insights from experimental challenges using primary and successive exposures. Vet Res 46:139

40. Segarra A, Faury N, Pepin J-F, Renault T (2014) Transcriptomic study of 39 Ostreid herpesvirus 1 genes during an experimental infection. J Invert Pathol 119:5-11

41. Normand J, Li R, Quillien V, Nicolas J-L, Boudry P, Pernet F, Huvet A (2014) Contrasted survival under field or controlled conditions display associations between mRNA levels of candidate genes and response to OsHV-1 infection in the Pacific oyster, Crassostrea gigas. Mar Genomics 15:95-102

42. Pernet F, Barret J, Le Gall P, Corporeau C, Dégremont L, Lagarde F, Pepin JF, Keck N (2012) Mass mortalities of Pacific oysters Crassostrea gigas reflect infectious diseases and vary with farming practices in the Mediterranean Thau lagoon, France. Aquacult Environ Interact 2:215-237

43. Degremont $L$ (2013) Size and genotype affect resistance to mortality caused by OsHV-1 in Crassostrea gigas. Aquaculture 416:129-134

44. Martenot C, Oden E, Travaille E, Males JP, Houssin M (2011) Detection of different variants of Ostreid herpesvirus 1 in the Pacific oyster, Crassostrea gigas between 2008 and 2010. Virus Res 160:25-31

45. Oden E, Martenot C, Berthaux M, Travaille E, Malas JP, Houssin M (2011) Quantification of Ostreid herpesvirus 1 (OsHV-1) in Crassostrea gigas by real-time PCR: determination of a viral load threshold to prevent summer mortalities. Aquaculture 317:27-31

46. Paul-Pont I, Dhand NK, Whittington RJ (2013) Influence of husbandry practices on OsHV-1 associated mortality of Pacific oysters Crassostrea gigas. Aquaculture 412-413:202-214

47. Martenot C, Fourour S, Oden E, Jouaux A, Travaille E, Malas JP, Houssin M (2012) Detection of the OsHV-1 $\mu$ Var in the Pacific oyster Crassostrea gigas before 2008 in France and description of two new microvariants of the Ostreid hepesvirus 1 (OsHV-1). Aquaculture 338:293-296

48. Dégremont L (2011) Evidence of herpesvirus (OsHV-1) resistance in juvenile Crassostrea gigas selected for high resistance to the summer mortality phenomenon. Aquaculture 317:94-98
49. Randall RE, Goodbourn S (2008) Interferons and viruses: an interplay between induction, signalling, antiviral responses and viral countermeasures. J Gen Virol 89:1-47

50. Schneider WM, Dittmann Chevillotte M, Rice CM (2014) Interferonstimulated genes: a complex web of host defenses. Annu Rev Immunol 32:513-545

51. Green TJ, Raftos DA, Speck P, Montagnani C (2015) Antiviral immunity in marine molluscs. J Gen Virol 96:2471-2482

52. Green TJ, Montagnani C (2013) Poly I: C induces a protective antiviral immune response in the Pacific oyster (Crassostrea gigas) against subsequent challenge with Ostreid herpesvirus (OsHV-1 $\mu$ Var). Fish Shellfish Immunol 35:382-388

53. Schoggins JW, Rice CM (2011) Interferon-stimulated genes and their antiviral effector functions. Curr Opin Virol 1:519-525

54. Hiscott J, Grandvaux N, Sharma S, Tenoever BR, Servant MJ, Lin R (2003) Convergence of the NF-kappa B and interferon signaling pathways in the regulation of antiviral defense and apoptosis. Ann NY Acad Sci 1010:237-248

55. Jin J, Hu H, Li HS, Yu J, Xiao YB, Brittain GC, Zou Q, Cheng X, Mallette FA, Watowich SS, Sun S-C (2014) Non canonical NF-kB Pathway Controls the production of type I interferons in antiviral innate immunity. Immunity 40:342-354

56. Beutler B, Eidenschenk C, Crozat K, Imler J-L, Takeuchi S, Hoffmann JA, Akira S (2007) Genetic analysis of resistance to viral infection. Nat Rev Immunol 7:753-766

57. Hayden MS, Ghosh S (2004) Signaling to NF-kB. Genes Dev 18:2195-2224

58. Mercurio F, Manning AM (1999) NF-kB as a primary regulator of the stress response. Oncogene 18:6163-6171

59. Oeckinghaus A, Hayden MS, Ghosh S (2011) Crosstalk in NF-kB signaling pathways. Nat Immunol 12:695-708

60. Ludwig S, Planz O (2008) Influenza viruses and the NF-kappaB signaling pathway - towards a novel concept of antiviral therapy. Biol Chem 389:1307-1312

61. Green TJ, Barnes A (2010) Bacterial diversity of the digestive gland of Sydney rock oysters, Saccostrea glomerata infected with the paramyxean parasite, Marteilia sydneyi. J Appl Microbiol 109:613-622

62. Hernandez-Zarate G, Olmos-Soto I (2006) Identification of bacterial diversity in the oyster Crassostrea gigas by fluorescent in situ hybridization and polymerase chain reaction. J Appl Microbiol 100:664-672

63. Domeneghetti S, Varotto L, Civettini M, Rosani U, Stauder M, Pretto T, Pezzati E, Arcangeli G, Turolla E, Pallavicini A, Venier P (2014) Mortality occurrence and pathogen detection in Crassostrea gigas and Mytilus galloprovincialis close-growing in shallow waters (Goro Lagoon, Italy). Fish Shellfish Immunol 41:37-44

\section{Submit your next manuscript to BioMed Central and we will help you at every step:}

- We accept pre-submission inquiries

- Our selector tool helps you to find the most relevant journal

- We provide round the clock customer support

- Convenient online submission

- Thorough peer review

- Inclusion in PubMed and all major indexing services

- Maximum visibility for your research

Submit your manuscript at www.biomedcentral.com/submit 